\title{
INFORMASI KEUANGAN PERUSAHAAN TERHADAP HARGA SAHAM PERUSAHAAN BARANG KONSUMSI
}

\author{
Hermanto, Angelin Natasya \\ Fakultas Ekonomi dan Bisnis Universitas Esaunggul, Jakarta, Indonesia \\ Jalan Arjuna Utara no 9, Jakarta Barat \\ Hermanto@esaunggul.ac.id
}

\begin{abstract}
The research objective is to examine the effect of ROI, PER, DAR on the share price of companies in the consumer goods sector simultaneously, the effect of ROI on stock prices partially, the effect of PER on stock prices partially and the effect of DAR on stock prices partially. The sampling method used in this study was purposive sampling method with a total sample size of 100 data. This study uses a quantitative method that examines the causal relationship between variables and the dependent variable. The data used is secondary data in the form of information provided by third parties in the annual report which is taken through the company's official website or through the BEI official website. The results show that simultaneously ROI, PER, DAR have a positive effect on the share price of companies in the consumer goods sector, partially ROI has a positive effect on the stock price of companies in the consumer goods sector, partially PER does not affect the stock price of companies in the consumer goods sector. DAR has a positive effect on Company Stock Prices in the Consumer Goods Sector. This informs the ROI and DAR used as a basis for decision making.
\end{abstract}

Keywords: Return of Investment, Price to Earning Ratio, Debt to Asset Ratio

\begin{abstract}
Abstrak
Tujuan penelitian adalah untuk mengkaji pengaruh ROI, PER, DAR terhadap Harga Saham Perusahaan Sektor Barang Konsumsi secara simultan, pengaruh ROI terhadap Harga Saham secara parsial, pengaruh PER terhadap Harga Saham secara parsial serta pengaruh DAR terhadap Harga Saham secara parsial. Metode pengambilan sampel yang digunakan dalam penelitian ini adalah metode purposive sampling dengan jumlah total sampel sebanyak 100 data. Penelitian ini menggunakan metode kuantitatif yang menguji hubungan sebab akibat antar variabel dengan variabel dependen. Data yang digunakan adalah data sekunder berupa informasi yang diberikan oleh pihak ketiga annual report yang diambil melalui website resmi perusahaan atau melalui website resmi BEI. Hasil penelitian menunjukkan bahwa secara simultan ROI, PER, DAR berpengaruh positif terhadap Harga Saham Perusahaan Sektor Barang Konsumsi, secara parsial ROI, berpengaruh positif terhadap Harga Saham Perusahaan Sektor Barang Konsumsi, secara parsial PER tidak berpengaruh terhadap Harga Saham Perusahaan Sektor Barang Konsumsi, secara parsial DAR berpengaruh positif terhadap Harga Saham Perusahaan Sektor Barang Konsumsi. Hal ini menginformasikan ROI dan DAR digunakan sebagai dasar pengambilan keputusan.
\end{abstract}

Kata kunci: Return of Investment, Price to Earning Ratio, Debt to Asset Ratio

\section{Pendahuluan}

Pada bulan Juli 2019 harga saham perusahaan sektor barang konsumsi diberitakan rontok setelah dikeluarkannya laporan keuangan kuartal II dimana penjualan, pendapatan dan laba bersih beberapa perusahaan sektor barang konsumsi tercatat tumbuh tidak lebih dari 11\% (Saragih, 2019). Dalam berita lainnya menyebutkan harga saham perusahaan sektor barang konsumsi mengalami penurunan tajam (Dewi, 2019). Sedangkan menurut Evan Fajrin, penurunan indeks sektor ini disebabkan oleh sahamsaham emiten rokok yang turun cukup dalam akibat sentimen negatif berupa rencana kenaikan tarif bea cukai sebesar 23\% pada tahun 2020 (Qolbi, 2019). Penurunan harga saham ini dipengaruhi oleh kecenderungan 
investor yang lebih mengikuti perkembangan isu mengenai berita yang terinformasi dimedia cetak, maupun media lainnya daripada membaca informasi laporan keuangan perusahaan. Naik dan turunnya harga saham dapat pula disebabkan oleh beberapa hal seperti fundamental perusahaan, aksi korporasi perusahaan (hasil RUPS, keputusan stock split, jumlah dividen yang dibagikan, dll) serta proyeksi kinerja perusahaan di masa mendatang (planning perusahaan).

Return On Investment (ROI) karena Menurut Harahap (2005) laba dapat dijelaskan sebagai angka yang penting dalam laporan keuangan karena berbagai alasan, antara lain : laba merupakan dasar perhitungan pajak, pedoman dalam menentukan kebijakan investasi dan pengambilan keputusan, dasar dalam peramalan maupun kejadian ekonomi perusahaannya lain dimasa yang akan datang, dasar dalam perhitungan dan penilaian efisiensi dalam menjalankan perusahaan serta sebagai dasar dalam penilaian prestasi atau kinerja perusahaan (Gustina \& Wijayanto, 2015). Penelitian ini dilihat dari sudut pandang investor sehingga pengukuran laba terhadap investasi dirasa tepat.

\section{Price to Earning Ratio (PER)} dikarenakan PER menggambarkan apresiasi pasar terhadap perusahaan serta menunjukkan tingkat kepercayaan investor terhadap sebuah perusahaan. Dengan PER, investor dapat mengetahui harga wajar suatu saham dan bukan lagi sebuah perkiraan yang tidak pasti. Liu (2007) mengatakan bahwa proporsi Price to Earning Ratio (PER) adalah yang paling penting dalam mengevaluasi peralatan yang berbeda dalam mensurvei estimasi dan nilai perusahaan, lebih banyak lagi berdasarkan pengukuran arus kas atau keuntungan. (Ahmed et al., 2018).

Debt to Asset Ratio (DAR) dikarenakan investor perlu mengetahui keseluruhan hutang yang dimiliki perusahaan yang nantinya akan berpengaruh terhadap beban bunga dan mengurangi laba setiap tahun. Menurut Vatansever dan Hepsen (2013), indikator penting untuk melihat nilai perusahaan adalah Leverage Ratio. DAR dilakukan untuk mengukur seberapa besar aset perusahaan dibiayai oleh hutang atau seberapa besar hutang perusahaan mempengaruhi manajemen asetnya (Husna \& Satria, 2019). Pendapat lain dikemukakan oleh PWC (2017) yang menyatakan bahwa semakin tinggi rasio hutang maka semakin besar kemungkinan perusahaan tidak mampu melunasi kewajibannya, oleh karena itu pinjaman tersebut harus dibelanjakan dengan baik untuk memperoleh peluang keuntungan yang lebih besar (Husna \& Satria, 2019).

Menurut Anif Sarifudin dan Sodikin Manaf, Return saham merupakan faktor yang sangat penting dan harus diperhatikan oleh investor dalam melakukan investasi karena return saham menunjukkan prestasi emiten, pergerakan return saham searah dengan kinerja emiten. Apabila emiten mempunyai prestasi yang semakin baik maka keuntungan yang dapat dihasilkan dari operasi usaha semakin besar (Sarifudin \& Manaf, 2016). Oleh karena itu, penelitian ini akan berfokus pada pengaruh elemen-elemen keuangan terhadap kenaikan harga saham disamping berita-berita yang beredar terkait perusahaan barang konsumsi serta pengaruh Return On Investment, Price to Earning Ratio dan Debt to Asset Ratio dalam memberikan signal bagi investor terkait kondisi perusahaan. Penelitian ini dilakukan untuk membuktikan bahwa Return On Investment, Price to Earning Ratio dan Debt to Asset Ratio mempengaruhi keputusan investasi investor untuk mempercayakan modalnya kepada perusahaan yang menyebabkan harga saham perusahaan menjadi naik.

Dalam penelitian terdahulu yang dilakukan oleh E. Chuke N., Elias I. A. dan Christian I. dengan judul Effect of Cash Conversion Cycle on the Profitability of Public Listed Insurance Companies menyimpulkan bahwa Cash Conversion Cycle (CCC) memiliki pengaruh negatif terhadap profitabilitas perusahaan. E. Chuke N., Elias I. A. dan Christian I. memberikan saran kepada peneliti selanjutnya melibatkan semua perusahaan asuransi di Nigeria harus dilakukan. Selain itu, studi lebih lanjut tentang topik tersebut harus menggunakan lebih banyak variabel dan memperpanjang periode studi untuk tujuan generalisasi hasil. Dalam penelitian E. Chuke N., Elias I. A. dan Christian I. masih ditemukan beberapa kelemahan seperti jumlah populasi dalam penelitian ini hanya berjumlah 20 
perusahaan, metode uji yang digunakan dalam penelitian ini tidak dijelaskan secara lebih jelas oleh peneliti. Variabel dependen dalam penelitian ini memiliki cakupan yang kurang luas.

Berdasarkan penelitian E. Chuke N., Elias I. A. dan Christian I., "Adjusted $R$ Square yang dihasilkan sebesar 0,640769 (64,1\%) atau dapat diartikan bahwa peresentase sumbangan pengaruh variabel Cash Conversion Cycle (CCC) terhadap variabel dependen dapat menjelaskan Return On Asset (ROA) sebesar $64,1 \%$. Sedangkan sisanya sebesar 35,9\% dijelaskan atau dipengaruhi oleh variabel lain yang tidak diamati dalam model penelitian ini" (Nwude et al., 2018).

Namun demikian, terdapat beberapa kesenjangan diantara penelitian-penelitian terdahulu seperti tidak konsistennya hasil dari penelitian sebelumnya terkait pengaruh masing-masing variabel independen terhadap harga saham, bahwa masing-masing variabel Return On Investment, Price to Earning Ratio dan Debt to Asset Ratio yang akan diteliti dalam penelitian ini sudah pernah diteliti sebelumnya namun belum pernah dilakukan penelitian terhadap keterkaitan seluruh variabel secara simultan dan belum pernah dilakukan penelitian terhadap perusahaan sektor barang konsumsi yang terdaftar di Bursa Efek Indonesia periode 2015-2019.

Tujuan penelitian ini adalah untuk mengkaji pengaruh variabel ROI, PER dan DAR secara simultan terhadap harga saham, mengkaji pengaruh variabel Return On Investment secara parsial terhadap harga saham, untuk mengkaji pengaruh variabel Price to Earning Ratio secara parsial terhadap harga saham serta untuk mengkaji pengaruh variabel Debt to Asset Ratio secara parsial terhadap harga saham.

\section{Metode Penelitian Sumber Data}

Pengumpulan data untuk mendukung proses penelitian ini dengan menggunakan kajian literatur, artikel, pustaka, informasi data stream, website resmi Bursa Efek. Sumber data yang dijadikan dasar data oleh peneliti dalam penelitian ini adalah data sekunder, yaitu data yang telah di olah dari pihak pertama dan telah dipublikasikan kepada umum. Data harga saham perusahan diperoleh dari website BEI (Bursa Efek Indonesia) dan data laba perusahaan di peroleh dari website BEI (Bursa Efek Indonesia), ICMD (Indonesian Capital Market Directory) serta website Perusahaan yang akan dijadikan sampel.

\section{Jenis Data}

Jenis data dalam penelitian ini adalah data kuantitatif, yaitu data yang berbentuk bilangan atau angka berdasarkan perhitungan matematis yang kemudian memberikan gambaran atas suatu fenomena kasus yang terjadi. Pada penelitian ini peneliti mengunakan data dalam bentuk rasio yaitu ROI, PER, DAR dan In Harga Saham.

\section{Populasi dan Sampel}

Populasi adalah wilayah generalisasi yang terdiri atas obyek/subyek yang mempunyai kualitas dan karakteristik tertentu yang ditetapkan oleh peneliti untuk dipelajari dan kemudian ditarik kesimpulannya, Sugiyono (2009:80). Populasi dalam penelitian ini adalah seluruh perusahaan yang telah terdaftar di Bursa Efek Indonesia (go public). Dengan alasan, data yang diperlukan oleh peneliti telah dipublikasikan dan data dapat di akses lebih mudah, cepat, kapan saja sehingga waktu penelitian lebih efektif dan efisien. Populasi dari penelitian ini merupakan perusahaan yang tercatat di Bursa Efek Jakarta yang berjumlah 461 perusahaan.

Sampel adalah bagian dari populasi yang memenuhi syarat perwakilan dari keseluruhan populasi, Reid dan Bojanic (2001).

Teknik pengambilan sampel dilakukan melalui metode purposive sampling, yaitu pengambilan sampel dengan syarat penyaringan tertentu yang telah ditetapkan untuk ketepatan penelitian. Syarat-syarat penyaringan tersebut yaitu:

a) Perusahaan manufaktur yang secara konsisten terdaftar di Bursa Efek Indonesia selama periode penelitian

b) Perusahaan manufaktur yang bukan merupakan sektor barang konsumsi.

c) Perusahaan sektor barang konsumsi yang tidak secara konsisten terdaftar di Bursa Efek Indonesia selama periode penelitian.

d) data yang diperlukan oleh peneliti telah dipublikasikan dan data dapat di akses 
lebih mudah, cepat, kapan saja sehingga waktu penelitian lebih efektif dan efisien.

Dari populasi sebanyak 156 perusahaan Manufaktur, diperoleh 20 perusahaan yang memenuhi kriteria sampel.

\section{Analisis Data}

\section{Uji Normalitas Data}

Pengujian tentang kenormalan distribusi data, karena data tersebut harus terdistribusi secara normal atau mengikuti bentuk distribusi normal.

Metode yang lebih akurat untuk menguji normalitas adalah dengan uji Kolmogorov Smirnov, yaitu dengan melihat angka profitabilitas signifikan, yaitu :

(i) Jika (Asymp. Sig.) < 0.05 maka distribusi data tidak normal.

(ii) Jika (Asymp. Sig) > 0.05 maka distribusi data normal.

Pada penelitian ini penulis mengunakan alat analisis data Kolmogorov Smirnov.

\section{Uji Multikolinieritas}

Uji ini bertujuan untuk menguji apakah pada model regresi ditemukan adanya korelasi antar variabel bebas (independen). Model regresi yang baik seharusnya tidak terjadi korelasi di antara variabel independen. Untuk mengetahui adanya multikolinearitas, dapat dilihat dari Value Inflation Factor (VIF). Apabila nilai VIF $>10$, terjadi multikolinieritas. Sebaliknya, jika VIF $<10$, tidak terjadi multikolinearitas (Wijaya, 2009:119).

\section{Uji Heteroskedastisitas}

Heteroskedastisitas mempunyai suatu pemahaman bahwa varian dari residual suatu pengamatan ke pengamatan yang lain berbeda. Untuk mengetahui ada atau tidaknya heteroskedastisitas yaitu dengan melihat grafik Plot antara nilai prediksi variabel terikat (dependen) yaitu ZPRED dengan residualnya SRESID. Deteksi ada atau tidaknya heteroskedastisitas dapat dilakukan dengan melihat ada tidaknya pola tertentu pada grafik scatterplot antara SRESID dan ZPRED dimana sumbu $Y$ adalah $Y$ yang telah diprediksi, dan sumbu $X$ adalah residual $(Y$ prediksi $-Y$ sesungguhnya) yang telah di-studentized.

Dasar analisisnya adalah sebagai berikut:
1) Jika ada pola tertentu dan tidak stabil, seperti titik-titik yang ada membentuk pola bergelombang, melebar kemudian menyempit, maka mengindikasikan telah terjadi heteroskedastisitas.

2) Jika ada pola yang jelas, serta titik-titik menyebar di atas dan di bawah angka 0 pada sumbu $\mathrm{Y}$, maka tidak terjadi heteroskedastisitas.

\section{Uji Autokorelasi}

Uji autokorelasi merupakan pengujian asumsi dalam regresi dimana variabel dependen tidak berkorelasi dengan dirinya sendiri. Maksud korelasi dengan diri sendiri adalah bahwa nilai dari variabel dependen tidak berhubungan dengan nilai variabel itu sendiri, baik nilai variabel sebelumnya atau nilai periode sesudahnya (Santosa\&Ashari, 2005:240).

Dasar pengambilan keputusannya adalah sebagai berikut:

(i) Angka D-W di bawah -2 berarti ada autokorelasi positif

(ii) Angka D-W diantara -2 sampai +2 berarti tidak ada autokorelasi

(iii) Angka $\mathrm{D}-\mathrm{W}$ di atas +2 berarti ada autokorelasi negatif

\section{Uji Hipotesis}

Analisis regresi linier berganda ini digunakan untuk mengetahui ada tidaknya pengaruh dari variabel bebas atau independen terhadap atau dependent.

\section{Uji t}

Uji $t$ digunakan untuk mengetahui apakah variabel-variabel independen secara parsial berpengaruh atau tidak terhadap variabel dependen. Derajat signifikansi yang digunakan adalah 0,05. Apabila nilai signifikan lebih kecil dari derajat kepercayaan maka kita menerima hipotesis alternatif, yang menyatakan bahwa suatu variabel independen secara parsial mempengaruhi variabel dependen.

\section{Uji F}

Uji $F$ digunakan untuk mengetahui apakah variabel-variabel independen secara simultan berpengaruh signifikan terhadap variabel dependen. Apabila nilai $\mathrm{F}$ hitung lebih 
besar daripada nilai $F$ tabel maka semua variabel independen secara simultan berpengaruh signifikan terhadap variabel dependen.

\section{Koefisien determinasi $\left(\mathbf{R}^{2}\right)$}

Koefisien determinasi digunakan untuk mengetahui seberapa besar hubungan dari beberapa variabel dalam bentuk persentase. Koefisien determinasi akan menjelaskan seberapa besar perubahan atau variasi suatu variabel bisa dijelaskan oleh perubahan atau variasi pada variabel yang lain (Santosa\&Ashari, 2005:125). Nilai antara 0 dan 1 , jika hasil lebih mendekati angka 0 berarti kemampuan variabel-variabel independen dalam menjelaskan variasi variabel amat terbatas. Tapi jika hasil mendekati angka 1 berarti variabel-variabel independen memberikan hampir semua informasi yang dibutuhkan untuk memprediksi variasi variabel dependen.

\section{Uji Statistik Regresi}

Analisis regresi linier digunakan untuk menganalisis hipotesis dalam penelitian ini dan tingkat signifikansi yang digunakan sebesar 5\% (Masson, 1999). Adapun analisis regresi dapat dirumuskan sebagai berikut:

LNHS = b0 + b1ROI + b2PER+ b3DAR + E

\section{Variabel Penelitian}

Variabel adalah lambang / simbol yang dapat dilekatkan yang besarnya berubah-ubah, bervariasi, membentuk sekumpulan data atau informasi. Penelitian ini menggunakan dua macam variabel, yaitu variabel bebas (independent) dan variabel terikat (dependent).

\section{Jenis Variabel}

Sebagai variabel terikat (dependent) adalah Dividen dan sebagai variabel bebas (independent) adalah ROI, PER, DAR Dan LNHS

\section{Definisi Operasional Variabel Dependen}

Variabel dependen pada penelitian ini adalah Harga Saham. Pengertian Dividen adalah tanda bukti penyertaan kepemilikan modal atau dana pada suatu perusahaan, kertas yang tercantum dengan jelas nilai nominal, nama perusahaan dan diikuti dengan hak kewajiban yang dijelaskan kepada setiap pemegangnya, serta persediaan yang siap untuk dijual. Dalam variabel ini mengunakan skala nominal.

\section{Variabel Independen}

Variabel Independen pada penelitian ini adalah Return On Invesment, Price Earning Ratio dan Debt Asset Ratio.

\section{Return On Invesment}

Return On Invesment adalah kemampuan emiten dalam menghasilkan keuntungan, semakin kecil rasionya maka semakin baik. Dalam variabel ini mengunakan skala rasio

\section{Price Earning Ratio}

Price earning ratio adalah untuk mengukur kemampuan perusahaan dengan keseutuhan dana yang ditanamkan dalam aktiva yang digunakan untuk operasi perusahaan untuk menghasilkan keuntungan. Dalam variabel ini mengunakan skala rasio.

\section{Debt Asset Ratio}

Debt Asset Ratio adalah untuk mengukur seberapa banyak aset yang dibiayai oleh hutang. Dalam variabel ini mengunakan skala rasio.

Berdasarkan hipotesis di atas, maka dapat digambarkan model penelitian sebagai berikut:

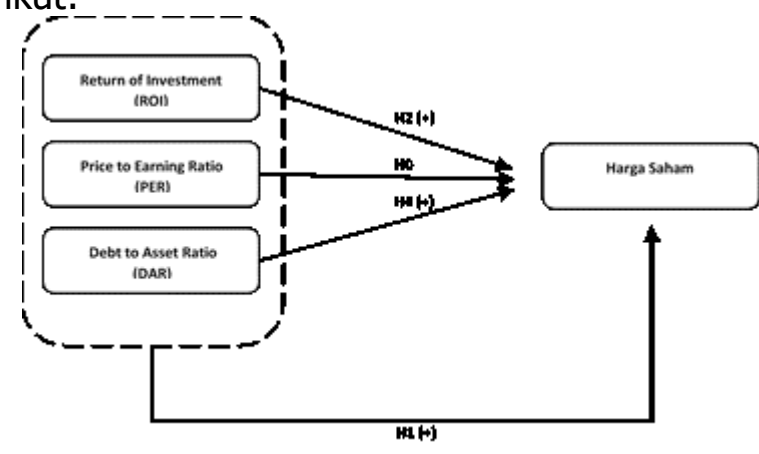

Gambar 1

Sumber diolah oleh peneliti 


\section{Hasil dan Pembahasan}

\section{Analisis Statistik Deskriptif}

Variabel ROI memiliki nilai min. 0,06 (SKBM) dan maks. 6.753,78 (DLTA) serta mean 72,3417 dengan Std. Deviation sebesar 674,94581. Variabel PER memiliki nilai min. 1,66 (MERK) dan maks. 136,67 (SKBM) serta mean 23,2844 dengan Std. Deviation sebesar 17,17471. Variabel DAR memiliki nilai min. 0,07 (SIDO) dan maks. 0,74 (UNVR) serta mean 0,3276 dengan Std. Deviation sebesar 0,15640. Variabel Harga Saham memiliki nilai min. 185 (WIIM) dan maks. 78.300 (GGRM) serta mean 9.071,3100 dengan Std. Deviation sebesar $16.844,52129$.

\section{Analisis Regresi Linear Berganda}

Berdasarkan hasil perhitungan Software Statistik, diperoleh persamaan sebagai berikut :

$$
\mathrm{HS}=8.588+0.784_{\mathrm{ROI}}+0.232_{\mathrm{PER}}+1.370_{\mathrm{DAR}}+\mathrm{e}
$$

Keterangan :
$12.217=$ Harga Saham
$8.588=$ Konstanta
$0.784=$ Koefisien Regresi dari Return On Investment
$0.232=$ Koefisien Regresi dari Price to Earning Ratio
$1.370=$ Koefisien Regresi dari Debt to Asset Ratio
$1.243=$ Variabel pegganggu (residual)

\section{Nilai konstanta (a)}

Dalam persamaan tersebut, diketahui besaran nilai konstanta (a) sebesar 8.588, yang mengartikan bahwa jika variabel Return On Investment (ROI), Price to Earning Ratio (PER) dan Debt to Asset Ratio (DAR) sama dengan 0 (nol), maka harga saham akan sebesar 8.588 satuan.

\section{Koefisien Regresi Return On Investment (ROI) sebesar 0.784}

Dalam persamaan tersebut, diketahui besaran nilai koefisien ROI $\left(b_{1}\right)$ sebesar 0.784 yang mengartikan bahwa terdapat hubungan searah (positif) antara ROI dengan Harga Saham. Artinya dengan peningkatan ROI sebesar satu satuan, akan mempengaruhi peningkatan Harga Saham $(Y)$ sebesar 0.784 dengan asumsi variabel PER dan DAR konstan.

\section{Koefisien Regresi Price to Earning Ratio (PER) sebesar 0.232}

Dalam persamaan tersebut, diketahui besaran nilai koefisien PER $\left(b_{2}\right)$ sebesar 0.232 yang mengartikan bahwa terdapat hubungan searah (positif) antara PER dengan Harga Saham. Artinya dengan peningkatan PER sebesar satu satuan, akan mempengaruhi peningkatan Harga Saham $(Y)$ sebesar 0.232 dengan asumsi variabel ROI dan DAR konstan.

\section{Koefisien Regresi Debt to Asset Ratio (DAR) sebesar 1.370}

Dalam persamaan tersebut, diketahui besaran nilai koefisien DAR $\left(b_{3}\right)$ sebesar 1.370 yang mengartikan bahwa terdapat hubungan positif (searah) antara DAR dengan Harga Saham. Artinya dengan peningkatan DAR sebesar satu satuan, akan mempengaruhi peningkatan Harga Saham $(Y)$ sebesar 1.370 dengan asumsi variabel ROI dan PER konstan.

\section{Koefisien Determinasi}

Besaran Adjusted $R$ Square sebesar 0.328. Hasil ini menunjukkan bahwa Return On Investment (ROI), Price to Earning Ratio (PER) dan Debt to Asset Ratio (DAR) dapat menjelaskan harga saham sebesar $32.8 \%$ dan $67.2 \%$ dijelaskan oleh faktor lain seperti harga saham masa lalu, volume bid dan volume perdagangan ataupun rasio-rasio keuangan lainnya yang tidak dikaji dalam penelitian ini.

\section{Uji Normalitas Data}

Menurut Ghozali (2014), data berdistribusi normal merupakan data yang baik yaitu memiliki nilai Sig. > 0.05 (Krisardiyansah \& Amanah, 2020). Jika memenuhi syarat, maka data penelitian dikatakan berdistribusi normal. 
Berdasarkan tabel 4.4, didapat hasil nilai Sig. ROI $0.200>0.05$, Sig. PER $0.200>$ 0.05 , Sig. DAR $0.163>0.05$, Sig. Harga Saham $0.193>0.05$. Hasil ini menunjukkan bahwa data berdistribusi normal.

\section{Uji Multikolinieritas}

Menurut Ghozali (2014:134), data yang tidak memiliki gejala multikolonieritas merupakan data yang baik yaitu memiliki nilai Tolerance $>0,1$ atau nilai VIF $<10$ (Krisardiyansah \& Amanah, 2020). Jika memenuhi syarat, maka data penelitian dikatakan baik (tidak memiliki gejala multikolonieritas). Berdasarkan tabel 4.5, didapat hasil nilai Tolerance ROI $0.972>$ 0.1 dan VIF $1.029<10$, Tolerance PER $0.984>0.1$ dan VIF $1.016<10$, Tolerance DAR $0.957>0.1$ dan VIF $1.045<10$. Hasil ini menunjukkan bahwa data dalam penelitian ini tidak memiliki gejala multikolonieritas.

\section{Uji Heterokedastisitas}

Penelitian ini menggunakan uji heterokedastisitas dengan metode uji glejser. Menurut Ghozali (2014:134), data yang tidak memiliki gejala heteroskedastisitas merupakan data yang baik dalam model regresi yaitu memiliki nilai Sig. > 0.05 (Krisardiyansah \& Amanah, 2020). Jika memenuhi syarat, maka data penelitian dikatakan baik (tidak memiliki gejala heteroskedastisitas dalam model regresi). Berdasarkan tabel 4.6, didapat hasil nilai Sig. ROI $0.273>0.05$, Sig. PER $0.072>0.05$, Sig. DAR) $0.960>$ 0.05. Hasil ini menunjukkan bahwa data dalam penelitian ini tidak memiliki gejala heteroskedastisitas.

\section{Uji Autokorelasi}

Penelitian ini menggunakan metode uji Durbin-Watson. Menurut Ghozali (2014:113), data yang tidak saling berkolerasi merupakan data yang baik yaitu memiliki nilai D-W diantara -2 sampai
+2. Jika memenuhi syarat, maka data penelitian dikatakan baik (tidak saling berkolerasi). Berdasarkan tabel 4.7, diperoleh hasil nilai D-W 0.690 (diantara -2 sampai +2). Hasil ini menunjukkan bahwa data dalam penelitian ini tidak saling berkolerasi.

\section{Uji F}

$\mathrm{H}_{1}$ : Pengaruh positif Return On Investment (ROI), Price to Earning Ratio (PER) dan Debt to Asset Ratio (DAR) terhadap Harga Saham. Berdasarkan hasil uji F dengan Software Statistik, diperoleh nilai Sig. sebesar 0.000 yang mengartikan bahwa nilai Sig. Uji F variabel ROI, PER dan DAR $<0.05$. Sehingga $\mathrm{H}_{0}$ ditolak dan $\mathrm{H}_{1}$ diterima (variabel $\mathrm{x}$ secara simultan berpengaruh terhadap variabel $y$ ).

\section{Uji t}

$\mathrm{H}_{2}$ : Pengaruh positif Return On Investment (ROI) terhadap Harga Saham. Berdasarkan hasil uji t dengan Software Statistik, didapat nilai Sig. ROI sebesar 0.000 yang mengartikan bahwa nilai Return On Investment (ROI) < 0.05. Sehingga $\mathrm{H}_{0}$ ditolak dan $\mathrm{H}_{2}$ diterima (Return On Investment secara parsial berpengaruh terhadap harga saham).

$\mathrm{H}_{3}$ : Pengaruh positif PER terhadap Harga Saham. Berdasarkan hasil uji $t$ dengan Software Statistik, didapat nilai Sig. PER sebesar 0.297 yang mengartikan bahwa nilai PER $>0.05$. Sehingga $\mathrm{H}_{3}$ ditolak dan $\mathrm{H}_{0}$ diterima (Price to Earning Ratio secara parsial tidak berpengaruh terhadap harga saham).

$\mathrm{H}_{4}$ : Pengaruh positif DAR terhadap Harga Saham. Berdasarkan hasil uji t dengan Software Statistik, diperoleh nilai Sig. DAR sebesar 0.000 yang mengartikan bahwa nilai DAR $<0.05$. Sehingga $\mathrm{H}_{0}$ ditolak dan $\mathrm{H}_{4}$ diterima (DAR secara parsial berpengaruh terhadap harga saham). 


\section{Kesimpulan}

Berdasarkan hasil penelitian di atas, dapat disimpulkan bahwa ROI, PER dan DAR secara simultan berpengaruh terhadap harga saham perusahaan sektor barang konsumsi yang terdaftar di Bursa Efek Indonesia (BEI) tahun 2015-2019. Besaran ROI, PER dan DAR secara bersama-sama membantu investor dalam mempertimbangkan terkait pengambilan keputusan investasi. Keputusan investor terkait investasi akan berdampak terhadap harga saham perusahaan sesuai dengan teori harga saham yang dikemukakan oleh Jogiyanto (2008:167), bahwa harga saham ditentukan oleh pelaku pasar melalui permintaan dan penawaran saham di pasar modal. ROI berpengaruh positif terhadap harga saham perusahaan sektor barang konsumsi yang terdaftar di Bursa Efek Indonesia (BEI) tahun 2015-2019. Besaran ROI yang baik, akan memberikan semangat kepada investor untuk menginvestasikan modalnya sehingga harga saham perusahaan akan meningkat.

Hal ini sesuai dengan signalling theory yang menyatakan bahwa semakin tinggi ROI sebuah perusahaan maka akan memberikan sinyal kepada investor bahwa kinerja perusahaan semakin efektif, sehingga meningkatkan daya tarik perusahaan dan minat investor serta menyebabkan naiknya harga perusahaan. PER tidak berpengaruh terhadap harga saham perusahaan sektor barang konsumsi yang terdaftar di Bursa Efek Indonesia (BEI) tahun 2015-2019. Hal ini berarti PER bukan merupakan bahan pertimbangan bagi investor saat akan menginvestasikan dana atau modalnya ke dalam sebuah perusahaan dan dapat pula dikarenakan pada penelitian terdahulu, sektor yang diteliti bukanlah sektor barang konsumsi.

Sehingga dalam hal melakukan investasi kepada perusahaan sektor barang konsumsi, investor tidak lagi meragukan PER setiap perusahaan dikarenakan barang konsumsi merupakan barang kebutuhan sehari-hari dan ekspektasi investor bahwa PER perusahaan sektor barang konsumsi pastilah baik. Hal ini menyebabkan PER perusahaan sektor barang konsumsi bukanlah menjadi hal yang penting dan utama bagi investor. DAR berpengaruh positif terhadap harga saham perusahaan sektor barang konsumsi yang terdaftar di Bursa Efek Indonesia (BEI) tahun 2015-2019. Besaran DAR yang besar memungkinkan perusahaan untuk menggunakan hutang nya sebagai modal operasional perusahaan untuk menghasilkan laba bagi perusahaan. DAR berpengaruh signifikan terhadap harga saham karena perusahaan yang mampu memenuhi kewajiban jangka panjangnya maka akan tercermin kinerja perusahaan yang baik dan dapat dikatakan bahwa perusahaan tersebut sehat. Kondisi perusahaan yang sehat dapat menciptakan kepercayaan dari masyarakat dan mampu menarik investor untuk menanamkan modalnya ke perusahaan tersebut. Sehingga meningkatnya DAR akan berpengaruh terhadap meningkatnya harga saham perusahaan.

Penelitian ini memiliki keterbatasan sampel penelitian dengan hanya 100 data sampel dan belum meneliti variabel lainnya yang dapat menjelaskan harga saham lebih dari variabel dalam penelitian ini. Saran yang dapat diberikan bagi peneliti selajutnya berdasarkan hasil penelitian ini adalah untuk dapat menganalisis faktor-faktor lain terhadap harga saham seperti menganalisis faktor teknikal (volume bid, harga saham masa lalu dan volume perdagangan) ataupun dengan menggunakan rasio-rasio keuangan lainnya dikarenakan Return On Investment (ROI), Price to Earning Ratio (PER) dan Debt to Asset Ratio (DAR) hanya dapat menjelaskan harga saham sebesar $32.8 \%$. Peneliti selanjutnya disarankan juga untuk menggunakan jumlah data sampel yang lebih banyak dan dalam kurun waktu yang lebih lama sehingga hasil penelitian lebih bisa menggambarkan kondisi yang sebenarnya.

Sehubungan dengan hasil penelitian ini dimana Price to Earning Ratio (PER) tidak memiliki pengaruh terhadap harga saham, maka diharapkan kepada peneliti selanjutnya untuk melakukan penelitian lebih lanjut terkait pengaruh Price to Earning Ratio (PER) terhadap harga saham atau keterkaitan Price to Earning Ratio (PER) dengan investasi.

Implikasi manajerial pada penelitian ini bagi pihak perusahaan untuk dapat memberikan kinerja semaksimal mungkin yang akan mencerminkannya dalam laporan keuangan untuk menarik minat investor. Bagi investor dan calon investor, agar dapat melihat 
besaran ROI, PER dan DAR sebelum melakukan investasi untuk melihat kondisi dan kinerja perusahaan.

\section{Daftar Pustaka}

Ahmed, F., Advani, N., \& Kanwal, S. (2018). Earnings Management and Dividend Policy: Empirical Evidence from Major Sectors of Pakistan. International Journal of Economics and Financial Issues, 8(3), 182-190.

Alam, S., Miah, R., \& Karim, A. (2016). Analysis on Factors that Affect Stock Prices: $A$ Study on Listed Cement Companies at Dhaka Stock Exchange. Research Journal of Finance and Accounting, January.

Dewi, H. K. (2019). Saham GGRM anjlok 20\%, IHSG melorot $1,82 \%$ ke 6.219 di akhir perdagangan hari ini. Kontan.Co.Id. https://investasi.kontan.co.id/news/sah am-ggrm-anjlok-20-ihsg-melorot-182ke-6219-di-akhir-perdagangan-hari-ini

Faila, I., \& Djawoto. (2017). Pengaruh ROI, ROE, TATO dan PER Terhadap Harga Saham Pada Perusahaan Telekomunikasi. Jurnal Ilmu Dan Riset Manajemen, 6(9), 1-16.

Gustina, D. L., \& Wijayanto, A. (2015). Analisis Rasio Keuangan Dalam Memprediksi Perubahan Laba. Management Analysis Journal, 1(2), 120-128.

Gustmainar, J., \& Mariani. (2018). Analisis Pengaruh Current Ratio, Debt To Equtiy Ratio, Gross Profit Margin, Return On Investment dan Earning Per Share Terhadap Harga Saham Pada Perusahaan LQ45 Yang Terdaftar Di Bursa Efek Indonesia Tahun 2010 2016. Bilancia: Jurnal IImiah Akuntansi, 2(4), 465-476 ISSN 2549-5704.

Hanadi, J., \& Hermanto, H. (2020). Analisis Pengaruh Faktor Keuangan Terhadap Pertumbuhan Laba. Jurnal Ekonomi.

Hermanto, H. (2018a). Analisis Pembagian Deviden Pada Perusahaan yang Tercatat di BEI. Jurnal Akuntansi Bisnis, 11(1), 41-53.

Hermanto, H. (2018b). Pengaruh Profitabilitas, Ukuran Perusahaan dan Kepemilikan Saham Publik Terhadap Return Saham dengan CSR Sebagai Variabel
Intervening. Jurnal Ekonomi.

Himmawati, U., \& Meiden, C. (2020). Relevansi Nilai Pajak Tangguhan. 5(2), 137-152.

Husna, A., \& Satria, I. (2019). Effects of Return on Asset, Debt to Asset Ratio, Current Ratio, Firm Size, and Dividend Payout Ratio on Firm Value. International Journal of Economics and Financial Issues, 9(5), 50-54.

Karnawati, Y. (2018). Faktor-Faktor yang Berpengaruh Terhadap Manajemen Laba dan Kinerja Perusahaan (Studi Empiris Pada Perusahaan Manufaktur). Jurnal Ekonomi, 9 (November).

Krisardiyansah, K., \& Amanah, L. (2020). Pengaruh Free Cash Flow, Leverage, Profitabilitas, Likuiditas dan Ukuran Perusahaan Terhadap Kebijakan Dividen. Current: Jurnal Kajian Akuntansi Dan Bisnis Terkini, 1(1), 132149.

https://doi.org/10.31258/jc.1.1.132-149

Luckieta, M., Amran, A., \& Alamsyah, D. P. (2020). The Fundamental Analysis of Stock Prices. September.

Nwude, E., Agbo, E., \& Ibe-Lamberts, C. (2018). Effect of Cash Conversion Cycle on the Profitability of Public Listed Insurance Companies. International Journal of Economics and Financial Issues, 8(1), 111-117.

Oktaviani. (2018). Teori Rasio. Sereal Untuk, $51(1), 51$

Pratama, G. (2019). Efisiensi Pasar Modal Indonesia Pada Tahun Pemilu 2019. Jurnal Ekonomi, 000(January), 169179.

https://www.researchgate.net/publicati on/338886471

Priliyastuti, N., \& Stella. (2017). Pengaruh Current Ratio, Debt to Asset Ratio, Debt to Equity Ratio, Return On Asset dan Price Earnings Ratio Terhadap Harga Saham. Jurnal Bisnis Dan Akuntansi, 19(1), 320-324.

Qolbi, N. (2019). Indeks saham sektor barang konsumsi turun, begini pendapat analis. Kontan.Co.Id.

https://investasi.kontan.co.id/news/inde ks-saham-sektor-barang-konsumsiturun-begini-pendapat-analis

Rahman, A. A. A. A. (2017). The Relationship 
Between Solvency Ratios and Profitability Ratios: Analytical Study in Food Industrial Companies Listed in Amman Bursa. International Journal of Economics and Financial Issues, 7(2), 86-93. http: www.econjournals.com

Saragih, H. P. (2019, July 29). Kinerja Kurang Memuaskan, Saham Barang Konsumsi Rontok. CNBC Indonesia. https://www.cnbcindonesia.com/market /20190729132040-17-88257/kinerjakurang-memuaskan-saham-barangkonsumsi-rontok

Sarifudin, A., \& Manaf, S. (2016). Pengaruh Arus Kas Operasi, Arus Kas Investasi, Arus Kas Pendanaan dan Laba Bersih Terhadap Return Saham Pada Perusahaan Manufaktur Yang Terdaftar Di Bursa Efek Indonesia. 43, 1-12.

Supriyadi, S. G., \& Sunarmi. (2018). Pengaruh Current Ratio (CR), Debt to Asset Ratio (DAR), Earning Per Share (EPS), Dividen Payout Ratio (DPR) Terhadap Harga Saham Pada Perusahaan Manufaktur Sektor Barang Konsumsi yang Terdaftar di Bursa Efek Indoensia Periode 2010-2014. Jurnal Education and Economics (JEE), 01(04), 450-463.

Wangarry, A. R., Poputra, A. T., \& Runtu, T. (2015). Pengaruh Tingkat Return on Investment (ROI), Net Profit Margin (NPM) dan Debt to Equity Ratio (DER) Terhadap Harga Saham Perbankan Di Bursa Efek Indonesia (BEI). Jurnal Riset Ekonomi, Manajemen, Bisnis Dan Akuntansi, 3(4), 470-477.

Warizal, N., \& Setiawan, A. B. (2019). Return On Investment (ROI), Economic Value Added (EVA) dan Return Saham: Studi Empiris Pada Perusahaan LQ45. Jurnal Akunida, 5, 47-58.

Yulianti, A., Paramita, R. W. D., \& Liyundira, F. S. (2019). Pengaruh Return on Invesment, Earning Per Share dan Return on Equity Terhadap Harga Saham Perusahaan Manufaktur Yang Terdaftar Di Bursa Efek Indonesia Tahun 2015-2017. 2(July 2019), 113119.

https://103.247.10.251/index.php/ekobi s/article/view/470 